\title{
PENGARUH EKSTRAKURIKULER KEROHANIAN ISLAM TERHADAP PERILAKU SISWA DI BENGKULU
}

\section{THE EFFECT OF ISLAMIC LOSS OF EXTRACURRICULAR STUDENT BEHAVIOR IN BENGKULU}

\author{
Pasmah Chandra \\ Institut Agama Islam Negeri Bengkulu, Indonesia \\ Email: pasmah@iainbengkulu.ac.id \\ Nelly Marhayati \\ Institut Agama Islam Negeri Bengkulu, Indonesia \\ Email: nellymarhayati@iainbengkulu.ac.id \\ Ersa Mala Aliza \\ Institut Agama Islam Negeri Bengkulu, Indonesia \\ Email: ersamalaaliza@gmail.com
}

\begin{abstract}
Abstrak
Penelitian ini bertujuan untuk mengetahui pengaruh kegiatan ekstrakurikuler kerohanian Islam terhadap tingkah laku siswa di SMA Negeri 10 Kota Bengkulu. Jenis penelitian yaitu penelitian kuantitatif dengan pendekatan deskriptif. Teknik pengumpulan data yaitu angket, observasi, wawancara dan dokumentasi. Sampel pada penelitian ini adalah seluruh populasi siswa yang mengikuti kegiatan ekstrakurikuler kerohanian Islam di SMA Negeri 10 Kota Bengkulu. Peneliti menggunakan teknik probability sampling berupa simple random sampling. Analisis data penelitian menggunakan analisis regresi linier sederhana, uji F, uji t dan koefisien determinasi $\left(\mathrm{R}^{2}\right)$ dengan bantuan SPPS 16. Hasil penelitian menunjukkan bahwa kegiatan ekstrakurikuler kerohanian Islam berpengaruh terhadap perilaku siswa. Hal ini dibuktikan berdasarkan $t_{\text {hitung }}$ sebesar 3,120 sedangkan $t_{\text {tabel }}$ sebesar 2,037 pada taraf signifikan 0,05. Berdasarkan hasil tersebut $t_{\text {hitung }}$ lebih besar daripada $t_{\text {tabel }}$. Maka dapat disimpulkan bahwa Ha diterima dan Ho ditolak sehingga terdapat pengaruh kegiatan ekstrakurikuler kerohanian Islam terhadap tingkah laku siswa sebesar $22,8 \%$ sedangkan sisanya $77,2 \%$ dipengaruhi oleh faktor lain yang tidak diteliti dalam penelitian ini.
\end{abstract}

Kata Kunci: ekstrakurikuler, eerohanian Islam, perilaku siswa

\section{Abstract}

The study is aimed at seeing how extracurricular Islamic spirituality affects student's behavior at SMA Negeri 10 Bengkulu. The kind of research that is quantitative research with a quantitative descriptive approach. The data-collection techniques of questionnaire, observation, interview and documentation. The sample in this study is all of the students who have participated in extracurricular Islamic Spirituality at SMA Negeri 10 Bengkulu. Researchers use probability sampling techniques of 
simple random sampling. Research data analysis using simple linier regression analysis, F-Test, $t$-test and coefficient determinations $\left(R^{2}\right)$ with help of SPSS 16. The finding of this studies extracurricular activities of Islamic spirituality affect student's behavior. This is evidenced by $t_{\text {count }}$ of 3,120 whereas $t_{\text {table }}$ of 2,037 at a significant level of 0.05. Based on these results $t_{\text {count }}$ is greater than the excpectation $t_{\text {chart }}$. Thus, it may be concluded that Ha was accepted and Ho is rejected so that there is an influence of Islamic spirituality extracurricular activities on student behavior by $22.8 \%$ while the remaining $77.2 \%$ is influenced by other factors not studied in this study.

Keywords: extracurricular, Islamic spirituality, student's behavior

\section{A. Pendahuluan}

Pendidikan merupakan salah satu hal yang memegang peranan yang sangat penting dalam kemajuan masa depan bangsa. ${ }^{1}$ Undang-undang Nomor 20 Tahun 2003 tentang Sistem Pendidikan Nasional, pemerintah mengusahakan dan menyelenggarakan satu sistem pendidikan nasional yang dapat meningkatkan keimanan dam ketakwaan kepada Tuhan Yang Maha Esa serta akhlak mulia dalam mencerdaskan kehidupan bangsa. $^{2}$

Pendidikan agama sendiri memiliki peranan dalam proses transformasi yang orientasinya untuk membentuk akhlak dan kepribadian yang pada akhirnya membentuk karakter sesuai dengan nilai-nilai ajaran Islam. ${ }^{3}$ Saat ini kondisi pendidikan di negara Indonesia cukup memperihatinkan dengan berbagai problematika yang ada. Norma dan nilai serta nilai-nilai ajaran agama Islam yang semakin memudar dalam proses pembelajaran yang pada akhirnya berakibat hilangnya jati diri dan karakter bangsa pada siswa menjadi salah penyebab timbulnya problematika pendidikan di Indonesia. ${ }^{4}$

Media atau wadah untuk membentuk peserta didik memiliki pola tingkahlaku yang baik ialah melalui kegiatan ekstrakrikuler yang diselenggarakan di sekolah formal. Salah satu kegiatan ekstarkurikuler yang menjadi wadah penanaman nilai-nilai Islami adalah kegiatan ekstrakurikuler kerohanian Islam (Rohis). ${ }^{5}$

\footnotetext{
${ }^{1}$ Ahmad Fatah Yasin, Dimensi-Dimensi Pendidikan Islam (Malang: UIN-Maliki Press, 2008), 15

${ }^{2}$ Kemendikbud, UU SISDIKNAS Nomor 20 Tahun 2003 (Jakarta: Kemendikbud, 2013), 18

${ }^{3}$ Departemen Agama RI, Al-Qur`an dan Terjemahannya: Al-Hikmah (Bandung: CV Penerbit Diponegoro, 2010), 78

${ }^{4}$ Kholid Musyaddad, "Problematika Pendidikan di Indonesia," Edu-Bio, Vol. 4 (2013): 77

${ }^{5}$ Siti Ubaidah, "Manajemen Ekstrakurikuler dalam Meningkatkan Mutu Sekolah," Al-Fikrah: Jurnal Kependidikan Islam IAIN Sulthan Thaha Saifuddin, Vol. 5 (2014): 20-30
} 
Pasmah Chandra, Nelly Marhayati, Ersa Mala Aliza: Pengaruh Ekstrakurikuler Kerohanian Islam terhadap Perilaku Siswa di Bengkulu

Kegiatan kerohanian Islam merupakan suatu bentuk tranformasi nilai atau ajaran Islam yang bertujuan membentuk tingkah laku atau karakter siswa menjadi lebih baik. ${ }^{6}$ Suharman mengatakan bahwa kegiatan kerohanian Islam ini juga betujuan memaksimalkan setiap potensi atau kemampuan siswa atau peserta didik melalui proses pembinaan baik potensi akademik dan non akademik dengan tetap mengedepankan norma, aturan, dan ajaran-ajaran agama yang terdapat dalam al-Qur`an dan hadis. ${ }^{7}$

Tujuan dari pelaksanaan kegiatan ekstrakurikuler kerohanian Islam juga mengacu kepada proses belajar mengajar, di mana kegiatan belajar pada kegiatan ekstrakurikuler mengarah kepada perubahan tingkah laku anak didik. ${ }^{8}$ Hal ini sebagaimana yang dikemukakan oleh Gagne dan Berliner mengenai teori behavioristik. Teori ini menyatakan bahwa perubahan tingkah laku yang terjadi pada seseorang merupakan hasil dari sebauh pengalaman. Belajar merupakan perubahan tingkah laku sebagai akibat dari adanya interaksi antara stimulus dan respon, yang hasilnya berbeda antara sebelum dan sesudah melakukan proses belajar. ${ }^{9}$

Penelitian ini juga diperkuat melalui data awal yang bersumber dari wawancara terhadap siswa di SMAN 10 Kota Bengkulu bahwa pendidikan agama sangat diperhatikan. Oleh karena pembelajaran PAI di dalam kelas hanya tiga jam pelajaran, maka hal itu sangatlah kurang bagi siswa untuk belajar mengenai agama Islam. Maka untuk mendukung mata pelajaran PAI tersebut, dibentuklah kegiatan ekstrakurikuler kerohanian Islam yang dilaksanakan setiap hari Rabu setelah selesai mengikuti mata pelajaran di kelas. Kegiatan ini dilakukan melalui berbagai bentuk kegiatan, seperti pemberian materi dari pembina, shalat berjamaah Zuhur dan Ashar, belajar membaca al-Qur`an.

Dilihat dari pernyataan di atas bahwa kegiatan kerohanian Islam di luar sekolah merupakan suatu hal yang sangat baik diikuti siswa. Namun kenyataan yang terjadi tidaklah demikian. Kegiatan kerohanian Islam kurang mendapat respon yang baik dari sebagian siswa, sehingga siswa yang mengikuti kegiatan ini terbilang hanya sedikit.

\footnotetext{
${ }^{6}$ M. Ali Noer, Syahraini Tambak, dan Harun Rahman, "Upaya Ekstrakurikuler Kerohanian Islam (ROHIS) dalam Meningkatkan Sikap Keberagamaan Siswa di SMK Ibnu Taimiyah Pekanbaru," Jurnal Pendidikan Agama Islam Al-Thariqah, Vol. 2, No. 1 (2017): 45-51

${ }^{7}$ Suharman, "Faktor Determinan Akhlak," Conciencia, Vol. 18, No. 2 (2018): 70-98

${ }^{8}$ Ani Nuryani dan Kama Abdul Hakam, "Kajian Pembinaan Akhlak Mulia Melalui Kegiatan Ekstrakurikuler Rohani Islam (ROHIS) di Sekolah (Studi di SMA Negeri 1 Lembang Kab. Bandung Barat)," Integritas: Jurnal Penelitian Pendidikan Karakter, Vol. 1, No. 2 (2013): 33-44

${ }^{9}$ Calvin S. Hall and Gardner Lindzey, Psikologi Kepribadian 3 Teori-Teori Sifat dan Behavioristik (Yogyakarta: Kanisius, 1993), 110
} 
Adapun hal yang ditemukan oleh peneliti saat mengikuti kegiatan kerohanian Islam ialah masih ada sebagian siswa yang mengikuti kegiatan ekstrakurikuler kerohanian Islam ternyata meninggalkan shalat wajib apabila berada di luar sekolah. Hal ini dibuktikan pada saat pembina kerohanian Islam bertanya kepada mereka satu persatu, dan masih ada sebagian siswa yang tidak mengikuti shalat zuhur berjama'ah ketika berada di sekolah. Jiwa sosial terhadap guru dan teman juga masih kurang.

Maka dari pernyataan tersebut terdapat kesenjangan antara teori ideal yang dikemukan oleh Gage dan Berliner yang mengatakan bahwa anak yang mendapat pengalaman baik dapat membentuk tingkah lakunya menjadi lebih baik. Idealnya dengan mengikuti kegiatan ekstrakurikuler kerohanian Islam dapat membentuk tingkah laku siswa menjadi lebih baik. Akan tetapi masih ada sebagian siswa yang belum mencerminkan tingkah laku yang baik padahal sudah mengikuti kegiatan ekstrakurikuler kerohanian Islam.

Sejauh ini studi tentang kegiatan ekstrakurikuler kerohanian Islam cenderung membahas pada aspek-aspek yang berkaitan, efektivitas kegiatan kerohanian Islam dan pelaksanaanan kegiatan kerohanian Islam itu sendiri. Beberapa, penelitian yang pernah dilakukan di antaranya: pertama, kajian mengenai peran kegiatan ekstrakurikuler kerohanian Islam terhadap pembinaan akhlak mulia. ${ }^{10}$ Kedua, penelitian yang membahas fungsi kerohanian Islam dalam mencegah radikalisme di era globalisasi. ${ }^{11}$ Ketiga, studi lain yang juga membahas mengenai fungsi kerohanian Islam dalam menangkal gerakan radikalisme di kalangan pelajar. $^{12}$ Keempat, penelitian yang membahas mengenai pembentukan sikap keagamaan siswa di SMK Ibnu Taimiyah Pekanbaru oleh Rohis. ${ }^{13}$ Ditemukan juga penelitian lain yang membahas mengenai sikap sosial keagamaan Rohis di SMA pada Delapan Kota di Indonesia. ${ }^{14}$ Berdasarkan kelima penelitian terdahulu, semua penelitian lebih menekankan pada fungsi, peran, posisi, dan efektivitas pelaksanaan kegiatan kerohanian Islam. Penelitian yang dilakukan

\footnotetext{
${ }^{10}$ Ashif Az Zafi, "Nilai Nasionalisme Kebangsaan Aktivis Rohis," Belajea: Jurnal Pendidikan Islam, Vol. 4, No. 2 (2019): 77-84

${ }^{11}$ Fachri Aidulsyah, Nurrahmad Wibisono, dan Yustia Atsanatrilova Adi, "Kerohanian Islam (Rohis) dalam Jurang Globalisasi Aktivisme Rohis SMAN di Eks Se-Karesidenan Surakarta (Solo Raya) Dalam Menjawab Tantangan Zaman,” Jurnal Pemikiran Sosiologi, Vol. 2, No. 2 (2017): 90-112

${ }^{12}$ Hayadin, "Tragedi Kecolongan Rohis Keterlibatan Alumni Rohis SMKN Anggrek pada Aksi Radikalisme," Al-Qalam, Vol. 19, No. 2, (2013): 23-35

${ }^{13}$ M. Ali Noer, Syahraini Tambak, dan Harun Rahman, "Upaya Ekstrakurikuler...," 63-76

${ }^{14}$ Marpuah, "Pelaksanaan Ekstrakurikuler Keagamaan Studi: Kegiatan Rohis Di SMAN Kota Cirebon," Al-Qalam, Vol. 22, No. 1 (2016): 50-63
} 
menggunakan pendekatan kualitatif. Penelitian ini sebagai pelengkap dari studi yang sudah ada dengan pendekatan kuantitatif. Adapun tujuan penelitian ialah untuk mengetahui pengaruh ekstrakurikuler kerohanian Islam terhadap tingkah laku siswa di Bengkulu.

\section{B. Metode}

\section{Tempat dan WaktuPenelitian}

Penelitian ini dilaksanakan di SMA Negeri 10 Kota Bengkulu. Penelitian ini dilakukan selama satu bulan dimulai pada tanggal 21 November sampai dengan 21 Desember 2019. Adapun alasan peneliti memilih lokasi penelitian antara lain: (1) SMA 10 memiliki siswa yang beragam latar belakang baik ekonomi, sosial dan pendidikan; (2) SMA 10 berada di wilayah yang tidak terlalu padat penduduknya dan berada di pinggir kota Bengkulu; dan (3) SMA 10 memiliki guru Rohis yang berkompeten.

\section{Populasi dan Sampel}

Populasi dalam penelitian ini adalah siswa di SMA Negeri 10 Kota Bengkulu yang mengikuti kegiatan ekstrakurikuler kerohanian Islam yang berjumlah 35 orang.

Tabel 1. Populasi

\begin{tabular}{cccc}
\hline \multirow{2}{*}{ No } & \multirow{2}{*}{ Kelas } & \multicolumn{2}{c}{$\begin{array}{c}\text { JumlahSiswa Yang Mengikuti } \\
\text { KegiatanEksrakurikulerRohis }\end{array}$} \\
\cline { 3 - 4 } & & Laki-laki & Perempuan \\
\hline 1 & X & 6 & 5 \\
2 & XI & 7 & 9 \\
3 & XII & 3 & 5 \\
& Jumlah & 16 & 19 \\
\hline & Total & & 35 \\
\hline
\end{tabular}

Populasi dalam penelitian ini kurang dari 100, maka peneliti mengambil keseluruhan siswa menjadi sampel dengan teknik probability sampling. ${ }^{15}$

\section{InstrumenPengumpulan Data}

a. Angket

Angket yang digunakan dalam penelitian ini berupa angket tertutup. Skala yang digunakan adalah skala Likert, yaitu skala yang digunakan untuk mengukur sikap, 2016), 99

\footnotetext{
${ }^{15}$ Sugiyono, Statistik Untuk Pendidikan," dalam Statistika Untuk Penelitian (Bandung: Alfabeta,
} 
pendapat, persepsi seseorang tentang fenomena sosial. ${ }^{16}$ Adapun jawaban dari setiap pertanyaan atas angket yang diberikan akan mendapat nilai sebagai berikut:

1) Selalu mendapat nilai 4

2) Sering mendapat nilai 3

3) Jarang mendapat nilai 2

4) Tidak pernah mendapat nilai 1

b. Dokumentasi

Dalam penelitian ini, dokumentasi digunakan untuk mengambil dan mengumpulkan data yang berkaitan dengan SMA Negeri 10 Kota Bengkulu. Data-data yang diperlukan dalam penelitian ini meliputi: sejarah berdirinya SMA Negeri 10 Kota Bengkulu, visi misi, jumlah siswa, jumlah guru yang mengajar, kegiatan kerohanian Islam.

\section{Teknik Analisis Data}

a. Uji Prasyarat

1) Uji Normalitas Data

Uji normalitas digunakan oleh peneliti untuk mengetahui apakah data tersebut berdistribusi normal atau tidak. Selain itu juga untuk menentukan pilihan rumus pada uji hipotesis nantinya.

2) Uji Linearitas

Uji linieritas penting digunakan untuk melihat hubungan linier atau tidak antara variabel kegiatan kerohanian Islam dengan tingkah laku siswa. Uji linearitas ini dapat dilakukan dengan menggunakan statistik uji F dengan rumus:

$$
\mathrm{F}=\frac{S_{T C}^{2}}{S_{G}^{2}}
$$

Uji linieritas dapat dilakukan dengan melihat perbandingan antara nilai $F_{\text {hitung }}$ dengan $\mathrm{F}_{\text {tabel }}$ pada taraf signifikansi $a=0,05$ dan $\mathrm{dk}_{\text {pembilang }}=\mathrm{k}-2$ dan $\mathrm{dk}_{\text {penyebut }}=\mathrm{n}-\mathrm{k}$. Apabila $F_{\text {hitung }} \leq \mathrm{F}_{\text {tabel }}$, maka akan diperoleh sebuah kesimpulan bahwa regresi berpola linier. $^{17}$

${ }^{16}$ Sugiyono, Metode Penelitian dan Pengembangan (Research and Development/R\&D), (Bandung: Alfabeta, 2016), 77

${ }^{17}$ Sugiyono, "Statistik Untuk Pendidikan...," 102 
Pasmah Chandra, Nelly Marhayati, Ersa Mala Aliza: Pengaruh Ekstrakurikuler Kerohanian Islam terhadap Perilaku Siswa di Bengkulu

b. Uji Hipotesis

1) Uji Analisis Regresi Linear Sederhana

Pada tahap selanjutnya ialah pengujian hipotesis penelitian, maka data yang telah diperoleh dari angket yang telah disebarkan akan dianalisis dengan sebuah metode statistik yang dikenal dengan rumus regresi linear sederhana sebagai berikut: ${ }^{18}$ $\mathrm{Y}=\mathrm{a}+\mathrm{bX}$

Keterangan:

$\mathrm{Y}=$ Subyek dalam variabel $\mathrm{Y}$ yang dipredeksikan

$\mathrm{A}=$ harga $\mathrm{Y}$ ketika harga $\mathrm{X}=0$ ( harga konstan)

$\mathrm{B}=$ angka arah atau koefisien regresi, yang menunjukkan angka peningkatam (+) ataupun penurunan (-) variabel Y yang didasarkan pada perubahan variabel X.

$\mathrm{X}=$ subyek pada variabel $\mathrm{X}$ yang mempunyai nilai tertentu

\section{Hipotesis Statistik}

Adapun hipotesis statistik dari penelitian ini adalah sebagai berikut:

Ho : Terdapat pengaruh kegiatan ekstrakurikuler kerohanian Islam (Rohis) terhadap perilaku siswa.

Ha : Tidak terdapat pengaruh kegiatan ekstrakurikuler kerohanian Islam (Rohis) terhadap perilaku siswa.

\section{Hasil Penelitian dan Pembahasan}

\section{Hasil Analisis Data}

a. Uji prasyarat

Uji prasyarat analisis data dalam penelitian ini dilakukan sebelum peneliti melakukan uji hipotesis penelitian dengan rumus regresi linear sederhana. Uji prasyarat yang dilakukan peneliti berupa uji normalitas dan linearitas.

a) Uji normalitas

Dalam hal ini peneliti menggunakan uji Kolmogorov-Smirnov sebagai uji normalitas. Dengan memanfaatkan apliaksi SPSS 16 maka didapatkan hasilnya sebagai berikut:

${ }^{18}$ Sugiyono, "Penelitian Kuantitatif," Pemaparan Metode Penelitian Kuantitatif (Bandung: Alfabeta, 2017), 121 
Tabel 2. Hasil Uji Normalitas

\begin{tabular}{|c|c|c|}
\hline \multicolumn{3}{|c|}{ One-Sample Kolmogorov-Smirnov Test } \\
\hline & & Unstandardized Residual \\
\hline $\mathrm{N}$ & & 35 \\
\hline Normal Parameters $^{\mathrm{a}}$ & Mean & .0000000 \\
\hline \multirow{4}{*}{$\begin{array}{ll}\text { Most } & \text { Extreme } \\
\text { Differences } & \end{array}$} & Std. Deviation & 3.21071601 \\
\hline & Absolute & .120 \\
\hline & Positive & .120 \\
\hline & Negative & -.084 \\
\hline \multicolumn{2}{|l|}{ Kolmogorov-Smirnov Z } & .711 \\
\hline \multicolumn{2}{|l|}{ Asymp. Sig. (2-tailed) } & .693 \\
\hline a. Test distribution is I & Normal. & \\
\hline
\end{tabular}

Dari data yang terdapat pada tabel di atas, maka terlihat bahwa nilai signifikan sebesar 0, 693. Nilai tersebut lebih besar dari taraf signifikasi 0,05 atau 5\%. Hal ini berarti menunjukkan bahwa dalam penelitian Ha diterima sementara $\mathrm{H}_{0}$ ditolak. Maka dapat peneliti dapat menyimpulkan bahwa data yang di uji berdistribusi normal.

b) Uji linearitas

Untuk mengetahui adanya hubungan linear atau tidak antara variabel kegiatan kerohanian Islam dan variabel tingkah laku siswa yang mengikuti kegiatan tersebut maka peneliti melakukan uji linearitas. Hasilnya bisa dilihat pada tabel output ANOVA tabel berikut:

Tabel 3. Hasil Uji Linearitas

\begin{tabular}{|c|c|c|c|c|c|c|c|}
\hline \multicolumn{8}{|c|}{ ANOVA Table } \\
\hline & & & $\begin{array}{l}\text { Sum of } \\
\text { Squares }\end{array}$ & Df & $\begin{array}{c}\text { Mean } \\
\text { Square } \\
\end{array}$ & $\mathrm{F}$ & Sig. \\
\hline \multirow{3}{*}{\multicolumn{2}{|c|}{$\begin{array}{l}\text { Tingkah Laku I } \\
\text { Siswa } \\
\text { Kegiatan } \\
\text { Ekstrakurikuler } \\
\text { Kerohanian } \\
\text { Islam }\end{array}$}} & $\begin{array}{l}\text { (Combine } \\
\text { d) }\end{array}$ & 222.469 & 13 & 17.113 & 1.553 & .179 \\
\hline & & Linearity & 103.390 & 1 & 103.390 & 9.382 & .006 \\
\hline & & $\begin{array}{l}\text { Deviation } \\
\text { from } \\
\text { Linearity }\end{array}$ & 119.079 & 12 & 9.923 & .900 & .561 \\
\hline \multicolumn{3}{|c|}{ Within Groups } & 231.417 & 21 & 11.020 & & \\
\hline \multicolumn{3}{|c|}{ Total } & 453.886 & 34 & & & \\
\hline
\end{tabular}


Ada dua cara yang dapat dilakukan untuk mengambil keputusan dalam melakukan penelitian ini. Pertama, melihat nilai signifikansi variabel; dan yang kedua dengan melihat nilai F. Keduanya dapat dilakukan dalam uji linearitas.

(1) Jika pengambilan keputusan dilihat pada cara yang pertama maka dapat dilihat dari nilai signifikasi (sig): dari data yang diapaparkan pada ouput di atas, maka diketahui nilai deviasi dari signifiaki linearitasnya adalah 0,561. Nilai yang didapatkan lebih besar dari 0,05. Sehingga peneliti dapat menyimpulkan bahwa ada hubungan linear antara variabel bebas yakni kegiatan ektrakurikuler kerohanian Islam dengan variabel terikat yakni tingkah laku siswa yang signifikan.

(2) Jika mengacu pada nilai F yang terdapat pada tabel ouput maka nilai yang diperoleh menunjukkan $F_{\text {hitung }}$ adalah 0,900 . Sehingga $F_{\text {hitungyang diperoleh lebih }}$ besar dari $F_{\text {tabelyakni }}$ 2,25. Maka dari itu, nilai $F_{\text {hitung }}$ lebih kecil dari nilai $F_{\text {tabel. }}$ Sehingga dapat ditarik kesimpulan terdapat hubungan linear antara variabel kegiatan ektrakurikuler kerohanian Islam (Rohis) yang diikuti siswa denagn tingkah laku yang signifikan.

\section{Hasil Uji Hipotesis}

a. Uji regresi linier sederhana

Untuk menguji pengaruh kegiatan ekstrakurikeler kerohanian Islam dengan tingkah laku siswa maka digunakan rumus uji regresi linear sederhana. Adapun hasil dari perhitungannya menggunakan SPSS.16 disajikan pada tabel di bawah ini:

Tabel 4. Hasil Analisis Regresi Linier Sederhana

\begin{tabular}{|c|c|c|c|c|c|c|}
\hline \multicolumn{7}{|c|}{ Coefficients $^{\mathrm{a}}$} \\
\hline & & $\begin{array}{r}\text { Unstan } \\
\text { Coeff }\end{array}$ & $\begin{array}{l}\text { ardized } \\
\text { cients }\end{array}$ & $\begin{array}{l}\text { Standardized } \\
\text { Coefficients }\end{array}$ & & \\
\hline \multicolumn{2}{|l|}{ Model } & $\mathrm{B}$ & Std. Error & Beta & $\mathrm{t}$ & Sig. \\
\hline \multirow[t]{2}{*}{1} & (Constant) & 25.838 & 5.738 & & 4.503 & .000 \\
\hline & $\begin{array}{l}\text { Kegiatan } \\
\text { Ekstrakurikuler } \\
\text { Kerohanian Islam }\end{array}$ & .541 & .174 & .477 & 3.120 & .004 \\
\hline $\begin{array}{l}\text { a. D } \\
\text { Tingkal }\end{array}$ & $\begin{array}{l}\text { ependent Variable: } \\
\text { hLakuSiswa }\end{array}$ & & & & & \\
\hline
\end{tabular}




\begin{tabular}{|c|c|c|c|c|c|}
\hline \multicolumn{6}{|c|}{ Model Summary } \\
\hline Model & $\mathrm{R}$ & $\begin{array}{c}\mathrm{R} \\
\text { Square }\end{array}$ & $\begin{array}{l}\text { Adjusted R } \\
\text { Square }\end{array}$ & $\begin{array}{l}\text { Std. Error } \\
\text { of the } \\
\text { Estimate }\end{array}$ & Durbin-Watson \\
\hline 1 & $.477^{\mathrm{a}}$ & .228 & .204 & 3.259 & 1.454 \\
\hline \multicolumn{6}{|c|}{ a. Predictors: (Constant), Kegiatan Ekstrakurikuler Kerohanian Islam } \\
\hline \multicolumn{6}{|c|}{ b. Dependent Variable: TingkahLakuSiswa } \\
\hline
\end{tabular}

Berdasarkan tabel di atas, maka dapat dibuat dalam sebuah persamaan uji regresi linier sederhana berikut ini:

$$
\begin{aligned}
& Y=a+b X \\
& Y=25.838+0.541 X
\end{aligned}
$$

Besarnya nilai $\mathrm{X}$ pada rumus dapat diperoleh melaui proses perhitungan dengan persamaan di atas yang merupakan regresi yang estiamsinya dapat dijelaskan berikut ini:

(a) 25.838 merupakan nilai konstanta (a) yang berarti apabila variabel bebas dalam penelitian ini yakni kegiatan ekstrakurikuler kerohanian Islam (Rohis) $=0$ (harga konstan), maka variabel terikat yakni tingkah lakusiswa nilainya25.838.

(b) 0,541 merupakan nilai koefisien regresi dari variabel bebas yakni kegiatan ekstrakurikuler keohanian Islam (Rohis) yang diikuti siswa. Hal ini berarti apabila kegiatan ekstarkurikuler yang diikuti mengalami kenaikan sebesar $1 \%$ maka secara otomatis tingkah laku siswa yang aktif dalam kegiatan tersebut juga akan meningkat $0,541 \%$.

(c) Tanda (+) pada koefisien regresi berarti memberikan petunjuk bahwa terdapat pengaruh yang positif dari variabel kegiatan kerohanian Islam terhadap variabel tingkah laku dan juga menunjukkan adanya peningkatan variabel tingkah laku yang didasarkan pada perubahan variabel kegiatan kerohanian Islam.

1) Uji t sebagai uji koefisien regresi linier sederhana

Adapun untuk mengetahui signifikasi pengaruh antara variabel mengikuti kegiatan kerohanian Islam (Rohis) terhadap perubahan tingkah laku siswa dapat dilakukan dengan uji t, dengan hipotesis penelitian: 
$\mathrm{H}_{0}$ : Tidak terdapat pengaruh signifikan kegiatan ekstrakurikuler kerohanian Islam (rohis) (X) terhadap tingkah laku siswa (Y)

Ha : Terdapat pengaruh signifikan kegiatan ekstrakurikuler kerohanian Islam (Rohis) (X) terhadap tingkah laku siswa (Y)

Berdasarkan hasil di atas menunjukkan bahwa $t_{\text {hitung }}=3,120$ dengan nilai signifikan sebesar 0,004 pada taraf signifikansi 5\% uji dua pihak dan $\mathrm{df}=\mathrm{n}-2-1=32$. Maka diperoleh $t_{\text {tabel }}$ sebesar 2,037. Sehingga bisa ditarik sebuah kesimpulan yakni Ha diterima dalam artian terdapat pengaruh signifikan pada kegiatan ektrakurikuler kerohanian ilsam (Rohis) terhadap pembentukan tingkah laku siswa. Namun yang perlu menjadi catatan bahwa tingkat signifikaasi dari kegiatan Rohis tersebut tidaklah terlampau tinggi hanya sebesar $22,8 \%$. Hal ini menunjukkan bahwa masih terdapat faktor lain yang juga mempengaruhi tingkah laku siswa yakni sebesar 77,2\%.

2) Uji koefisien determinasi $\left(\mathrm{R}^{2}\right)$

Hasil dari uji $\mathrm{R}^{2}$ menunjukkan bahwa kegiatan kerohanian Islam (Rohis) yang dilaksankan di sekolah bukanlah menjadi faktor utama yang mempengaruhi pembentukan tingkah laku siswa. Siswa yang aktif dalam kegiatan tersebut hanya bepengaruh 22,8\% terhadap tingkah laku mereka. Artinya dapat dipahami bahwa masih banyak pengaruhpengaruh lain sebesar 77,2\% yang akan membentuk tingkah laku siswa.

Keaktifan siswa dalam mengikuti kegiatan ekstrakurikuler yang diselenggarakan pihak sekolah menjadi salah satu faktor pendukung dalam mempengaruhi tingkah laku siswa. Salah satu kegiatan ekstarkurikuler yang menjadi wadah penanaman nilai-nilai Islami adalah kegiatan ekstrakurikuler kerohanian Islam. ${ }^{19}$

Kegiatan ekstrakurikuler kerohanian Islam dapat dijadikan sebagai wadah dalam menambah ilmu pengetahuan Islam karena mengingat bahwa mata pelajaran PAI di dalam kelas hanya satu kali pertemuan dalam satu minggu dan hanya belajar selama tiga jam pelajaran. Selain itu kegiatan ekstrakurikuler kerohanian Islam dapat pula dijadikan sebagai pengembangan pribadi seseorang, motivasi hidup, dan menggali potensi serta bakat bagi siswa karena dalam kegiatan ini dapat melatih siswa menjadi pribadi yang lebih baik lagi.

Hampir setiap pertemuan kegiatan Rohis guru pembimbing memberikan arahan dan nasihat serta pengajaran tentang keagaaman agar para siswa senantiasa melaksanakan

\footnotetext{
${ }^{19}$ Ani Nuryani dan Kama Abdul Hakam, "Kajian Pembinaan..."
} 
perintah dan menjauhi segala larangan Allah SWT., dan berakhlakul karimah sebagaimana yang telah diajarkan Nabi Muhammad SAW. melalui hadis sebagai pedoman dalam kehidupan sehari-hari. Pemberian nasihat seperti ini masih sangat dibutuhkan oleh anak-anak remaja seusia SMP dan SMA karena mereka masih labil dan belum paham mana yang mengandung mudharat dan maslahat serta masih cenderung mengikuti gaya hidup lingkungan sekitar dan teman sebayanya.

Kegiatan ekstrakurikuler kerohanian Islam yang ada di SMAN 10 Kota Bengkulu ialah sebagai berikut: pertama, shalat berjamaah. Shalat berjama'ah adalah kegiatan wajib dilaksanakan oleh siswa-siswi SMAN 10 Kota Bengkulu bukan hanya para siswa yang mengikuti kegiatan ekstrakurikuler kerohanian Islam saja, akan tetapi seluruh siswasiswi yang beragama Islam wajib mengikuti shalat berjamaah. Kegiatan shalat berjamaah yang dilaksanakan adalah shalat Zuhur dan Ashar yaitu dari hari Senin sampai hari Jum'at, akan tetapi untuk hari Jum'at siswa laki-laki shalat Jum'at berjama'ah terlebih dahulu kemudian setelah selesai shalat Jum'at baru siswinya shalat Zuhur berjama'ah.

Kedua, kegiatan membaca al-Qur`an. Pelaksanaan belajar membaca al-Qur`an pada kegiatan Rohis dilaksanakan sebelum penyampaian materi dari pembina Rohis. Pembina Rohis akan menunjuk salah satu dari anggota Rohis untuk memimpin membaca al-Qur`an kemudian diikuti oleh para siswa lainnya. Jika terdapat kesalahan dalam membaca, pembina Rohis akan membenarkan bacaannya dan siswa-siswi mengulangi bacaan tersebut. Siswa-siswi yang memimpin membaca al-Qur`an saling bergantian dari minggu ke minggu yaitu dengan ditunjuk oleh pembina Rohis secara acak sehingga semua siswa Rohis akan mendapatkan giliran. Ditunjuknya siswa yang mendapatkan giliran untuk bertugas sebagai pemandu dalam membaca al-Qur`an akan menjadi motivasi bagi siswa untuk belajar supaya tidak terjadi kesalahan di dalam membaca alQur`an.

Ketiga, pemberian materi (kuliah umum). Kuliah umum adalah kegiatan pemberian materi atau arahan kepada siswa dan siswa yang mengikuti kegiatan Rohis yang disampaikan oleh pembina Rohis. Biasanya pembina Rohis memberikan materi seperti tentang shalat, berbakti kepada orang tua, dosa ghibah, dosa berbuat buruk kepada orang lain dan tindakan lainnya yang merugikan orang lain. Dalam kegiatan ini diharapkan siswa dapat mengamalkannya dalam kehidupan mereka sehari-hari untuk tidak mengulangi kesalahan yang pernah mereka lakukan. 
Pasmah Chandra, Nelly Marhayati, Ersa Mala Aliza: Pengaruh Ekstrakurikuler Kerohanian Islam terhadap Perilaku Siswa di Bengkulu

Beradasarkan hasil penelitian mengenai pengaruh kegiatan ekstrakurikuler kerohanian Islam (Rohis) terhadap tingkah laku siswa yang, dengan cara memberikan angket yang berisi pertanyaan kepada para siswa sebagai responden yang berjumlah 27 orang maka dipeoleh hasil berikut ini:

a) Dari 10 (sepuluh) pertanyaan yang diberikan pada ke 27 (dua puluh tujuh) responden atau siswa yang aktif dalam mengikuti kegiatan kerohanian Islam (Rohis) maka pertanyaan nomor 10 yang memiliki pengaruh paling besar dalam membentuk tingkah laku siswa. Persentase dari item tersebut sebesar 63\%. Dari analisis pada variabel $\mathrm{X}$ ini dapat diketahui bahwa pelaksanaan kuliah umum atau ceramah agama secara klasikal dapat mempererat tali silaturahmi di antara siswa-siswi anggota Rohis.

b) Dari 13 pertanyaan yang diberikan kepada siswa untuk mengetahui perubahan tingkah laku siswa sebagai variabel terikat (Y) setelah mereka mengikuit kegiatan kerohanian Islam (Rohis) maka dapat di ketahui bahwa nomor pertanyaan ke-8 (delapan) yang paling mempengaruhi tingkah laku siswa. Persenatse dari pertnyaan tersebut yang berkaitan dengan sikap saling tolongmenolong ialah sebesar $57 \%$.

c) Berdasarkan olah data hasil uji analisis regeresi linear sederhana dengan persamaan $\mathrm{Y}=25.838+0.541 \mathrm{X}$ dengan memanfaatkan fasilitas aplikasi SPSS 16 maka dapat diperoleh nilai sebesar 0,541 sebagai koefisien regresi variabel kegiatan ekstrakurikuler kerohanian Islam (Rohis) sebagai variabel X.Hal ini berarti apabila kegiatan ekstrakurikuler kerohanian Islam (Rohis) mengalami kenaikan $1 \%$ maka secara otomatis pula tingkah laku siswa akan mengalami kenaikan $0,541 \%$. Tanda (+) memberikan petunjuk bahwa terdapat pengaruh yang positif dari variabel kegiatan kerohanian Islam (Rohis) terhadap variabel tingkah laku. Hal ini juga menunjukkan adanya peningkatan variabel tingkah laku siswa sebagai efek dari adanya pada perubahan variabel kegiatan kerohanian Islam.

d) Berdasarkan kriteria yang telah dibahas sebelumnya Ha dapat diterima jika $t_{\text {hitung }}$ lebih besar daripadatt $t_{\text {tabel }}$ dengan taraf signifikasi $5 \%$ uji dua pihak dan $\mathrm{df}=\mathrm{n}-2-1=32$. Dari hasil uji yang telah dilakukan menunjukkan bahwa $\mathrm{t}_{\text {tabel }}$ sebesar 2,037 sedangkan $t_{\text {hitung }}$ sebesar 3,120 pada taraf signifikasi 0,05. 
Berdasarkan hasil tersebut maka $t_{\text {hitung }}$ lebih besar daripadat $t_{\text {tabel }}$. Maka dapat di simpulkan bahwa $\mathrm{H}_{0}$ ditolak dan Ha diterima. Sehingga terdapat pengaruh kegiatan ekstrakurikuler kerohanian Islam (X) terhadap tingkah laku siswa $(\mathrm{Y})$.

e) Dari hasil uji $\mathrm{R}^{2}$ atau koefisien determinasi, diperoleh bahwa koefisien bernilai positif yang artinya terdapat pengaruh kegiatan kerohanian Islam dengan pembentukan tingkah laku siswa. Sehingga tingkat pengaruh terhadap tingkah laku siswa ditentukan dengan keaktifan siswa dalam. Merujuk pada nilai $\mathrm{R}$ square yang diperoleh yakni sebesar 0,228, maka diketahui jika kontribusi kegiatan ekstrakurikuler kerohanian Islam dalam mempengaruhi tingkah laku siswa hanaya sebesar 22,8\%. Hal ini menunjukkan bahwa maish banyak pengaruh atau faktor lain yang membentuk tingkah laku siswa di sekolah dengan kuantitas $77,2 \%$.

Dari perhitungan tersebut memberikn informasi bahwa kegiatan Rohis berpengaruh positif terhadap tingkah laku siswa. Semakin baik pembelajaran yang diberikan dalam kegiatan ekstrakurikuler kerohanian Islam, maka akan berdampak pada tingkah laku siswa yang akan akan semakin baik pula. Hasil dari penelitain ini sesuai atau memperkuat pendapat Novan Ardy Wiyani yang dikutip oleh Ummu Hanifah, menerangkan bahwa melalui kegiatan ekstrakurikuler Islam peningkatan iman dan takwa dapat dilakukan di sekolah dengan memfasilitasi peserta didik mengembangkan kegiatan yang bernuansa keagamaan melalui kegiatan ekstrakurikuler kerohanian Islam maka dapat membentuk akhlak siswa menjadi lebih baik. ${ }^{20}$

Rohis merupakan organisasi yang menyelenggarakan kegiatan-kegiatan keagamaan Islam di sekolah dengan melibatkan siswa secara langsung dalam kegiatan tersebut. Dengan berperan aktifnya siswa, maka kegiatan ekstrakurikuler kerohanian Islam dapat mempengarhui perilaku keagaamaan anngota yang mengikutinya. Sehingga siswa akan terbiasa dengan forum-forum kegiatan keagamaan yang pada akhirnya akan secara bertahap membentuk tingkah laku dan kepribadian siswa..

Banyaknya kegiatan keagamaan yang diikuti oleh siswa akan membuat siswa tersebut semakin luas dalam berpikir dan semakin banyak pula pengalaman keagamaan.

\footnotetext{
${ }^{20}$ Ummu Hanifah, "Pengaruh Keikutsertaan Siswa dalam Organisasi Kerohanian Islam (Rohis) Terhadap Perilaku Keagamaan Siswa SMA N 1 Sragen Tahun Pelajaran 2015/2016," Skripsi, (Semarang: UIN Walisongo, 2015), 120-131
} 
Dilihat dari tujuan pelaksanaan kegiatan ekstrakurikuler yang juga mengacu proses belajar mengajar sebagai proses pembentukan tingkah laku atau akhlak siswa. Hal ini sebagaimana dalam behaviorsm theory yang dikemukakan oleh Gage dan Berliner. Teori tersebut mengungkapkan bahwa pengalaman akan membentuk tingkah laku seseorang atau dalam artian tingkah laku akan terbentu melalui sebuah pengalaman. ${ }^{21}$ Jadi semakin baik dan banyak pengalaman yang diperoleh oleh seseorang maka akan berdampak pula pada tingkah laku yang terbentuk.

Berdasarkan teori yang digunakan maka dapat ditarik kesimpulan bahwa terdapat pengaruh yang signifikan antara kegiatan ekstarkurikuler kerohanian Islam terhadap tingkah laku siswa. Dengan demikian, terdapat kesesuaian antara teori yang ideal dengan hasil penelitian yang diperoleh. Namun dalam penelitian ini pengaruh dari kegiatan ekstarkurikuler kerohanian Islam terhadap tingkah laku siswa tidak terlalu besar yaitu $22,8 \%$. Adapun $77,2 \%$ lainya dipengaruhi oleh faktor atau pengaruh lain dalam membentuk tingkah laku, akhlak atau kepribadian siswa. Dari data yang diperoleh oleh peneliti hal tersebut memang sesuai dengan yang terjadi di lapangan, karena kegiatan ekstarkurikuler kerohanian Islam belum dilaksanakan secara maksimal. Kegaitan tersebut hanya dilakukan ssekali pertemuan dalam sepekan dengan durasi pertemuan tersebut hanya satu jam. Sehingga pengaruh dari kegiatan ekstarkurikuler kerohanian Islam tersebut hanya $22,8 \%$.

\section{Simpulan dan Saran}

\section{Simpulan}

Berdasarkan hasil penelitian dan pembahasan di atas, mengenai pengaruh kegiatan ekstrakurikuler kerohanian Islam terhadap perilaku siswa di SMAN 10 Kota Bengkulu, dapat disimpulkan bahwa terdapat atau adanya pengaruh dari kegiatan ekstrakurikuler kerohanian Islam (Rohis) terhadap perilaku siswa. Namun, berdasarkan hasil analisis data ternyata terdapat faktor lain yang juga mempengaruhi perilaku siswa. Faktor lain tersebut antara lain faktor pola asuh, latar belakang ekonomi dan juga kemampuan kognitif. Faktor lain tersebut tidak menjadi pembahasan pada penelitian ini. Disarankan untuk peneltii selanjutnya untuk melakukan penelitian lanjutan dengan menggunakan variabel dari faktor lain tersebut.

\footnotetext{
${ }^{21}$ Calvin S. Hall \& Gardner Lindzey, Psikologi Kepribadian..., 69
} 


\section{Saran}

Dengan melihat hasil dari penelitian yang menunjukkan bahwa terdapat pengaruh kegiatan ekstrakurikuler kerohanian Islam terhadap tingkah laku siswa di SMA Negeri 10 Kota Bengkulu, maka ada beberapa hal yang disarankan oleh penulis:

a. Kepada pihak sekolah diharapkan dapat memotivasi siswa-siswi agar mengikuti kegiatan ekstrakurikuler kerohanian Islam yang ada di sekolah.

b. Diharapkan kepada pembina kegiatan ekstrakurikuler kerohanian Islam untuk terus membimbing dan membina siswa-siswi yang mengikuti kegiatan ekstrakurikuler kerohanian Islam agar menjadi manusia yang berakhlak mulia.

c. Kepada siswa diharapkan dapat lebih giat dan semangat dalam mengikuti kegiatan ekstrakurikuler kerohanian Islam dan mampu mengamalkannya dalam kehidupan sehari-hari.

\section{E. Daftar Pustaka}

Aidulsyah, Fachri, Nurrahmad Wibisono, dan Yustia Atsanatrilova Adi. "Kerohanian Islam (Rohis) dalam Jurang Globalisasi Aktivisme Rohis SMAN di Eks SeKaresidenan Surakarta (Solo Raya) dalam Menjawab Tantangan Zaman." Jurnal Pemikiran Sosiologi, Vol. 2, No. 2 (2017): 90-112

Departemen Agama RI. Al-Qur`an dan Terjemahannya: Al-Hikmah. Bandung: CV Penerbit Diponegoro, 2010

Hall, Calvin S. \& Gardner Lindzey. Psikologi Kepribadian 3 Teori-Teori Sifat dan Behavioristik. Yogyakarta: Kanisius, 1993

Hanifah, Ummu. "Pengaruh Keikutsertaan Siswa dalam Organisasi Kerohanian Islam (Rohis) Terhadap Perilaku Keagamaan Siswa SMA N 1 Sragen Tahun Pelajaran 2015/2016.” Skripsi. Semarang: UIN Walisongo, 2015

Hayadin. "Tragedi Kecolongan Rohis Keterlibatan Alumni Rohis SMKN Anggrek pada Aksi Radikalisme." Al-Qalam, Vol. 19, No. 2, (2013): 23-35

Kemendikbud. UU SISDIKNAS Nomor 20 Tahun 2003. Jakarta: Kemendikbud, 2013

Marpuah. "Pelaksanaan Ekstrakurikuler Keagamaan Studi: Kegiatan Rohis Di SMAN Kota Cirebon.” Al-Qalam, Vol. 22, No. 1 (2016): 50-63

Musyaddad, Kholid. "Problematika Pendidikan di Indonesia." Edu-Bio, Vol. 4 (2013): 77

Noer, M. Ali, Syahraini Tambak, dan Harun Rahman. "Upaya Ekstrakurikuler Kerohanian Islam (ROHIS) dalam Meningkatkan Sikap Keberagamaan Siswa di SMK Ibnu Taimiyah Pekanbaru." Jurnal Pendidikan Agama Islam Al-Thariqah, Vol. 2, No. 1 (2017): 45-51

Nuryani, Ani dan Kama Abdul Hakam. "Kajian Pembinaan Akhlak Mulia Melalui Kegiatan Ekstrakurikuler Rohani Islam (ROHIS) di Sekolah (Studi di SMA 
Pasmah Chandra, Nelly Marhayati, Ersa Mala Aliza: Pengaruh Ekstrakurikuler Kerohanian Islam terhadap Perilaku Siswa di Bengkulu

Negeri 1 Lembang Kab. Bandung Barat)." Integritas: Jurnal Penelitian Pendidikan Karakter, Vol. 1, No. 2 (2013): 33-44

Sugiyono. "Penelitian Kuantitatif." Pemaparan Metode Penelitian Kuantitatif. Bandung: Alfabeta, 2017

Sugiyono. Metode Penelitian dan Pengembangan (Research and Development/R\&D). Bandung: Alfabeta, 2016

Sugiyono. Statistik Untuk Pendidikan." Dalam Statistika Untuk Penelitian. Bandung: Alfabeta, 2016

Suharman. "Faktor Determinan Akhlak." Conciencia, Vol. 18, No. 2 (2018): 70-98

Ubaidah, Siti. "Manajemen Ekstrakurikuler dalam Meningkatkan Mutu Sekolah." AlFikrah: Jurnal Kependidikan Islam IAIN Sulthan Thaha Saifuddin, Vol. 5 (2014): 20-30

Yasin, Ahmad Fatah. Dimensi-Dimensi Pendidikan Islam. Malang: UIN-Maliki Press, 2008

Zafi, Ashif Az. "Nilai Nasionalisme Kebangsaan Aktivis Rohis." Belajea: Jurnal Pendidikan Islam, Vol. 4, No. 2 (2019): 77-84 